Nat. Hazards Earth Syst. Sci., 18, 335-350, 2018

https://doi.org/10.5194/nhess-18-335-2018

(C) Author(s) 2018. This work is distributed under

the Creative Commons Attribution 3.0 License.

\title{
The 1997 Kronotsky earthquake and tsunami and their predecessors, Kamchatka, Russia
}

\author{
Joanne Bourgeois ${ }^{1}$ and Tatiana K. Pinegina ${ }^{2}$ \\ ${ }^{1}$ Department of Earth and Space Sciences, University of Washington, Seattle, WA 98195-1310, USA \\ ${ }^{2}$ Institute of Volcanology and Seismology, FEB RAS, 9 Piip Boulevard, Petropavlovsk-Kamchatsky, 683006, Russia
}

Correspondence: Joanne Bourgeois (jbourgeo@uw.edu)

Received: 15 May 2017 - Discussion started: 20 June 2017

Revised: 15 November 2017 - Accepted: 19 November 2017 - Published: 23 January 2018

\begin{abstract}
The northern part of the Kamchatka subduction zone (KSZ) experienced three tsunamigenic earthquakes in the 20th century - February 1923, April 1923, December 1997 - events that help us better understand the behavior of this segment. A particular focus of this study is the nature and location of the 5 December 1997 Kronotsky rupture $\left(M_{\mathrm{w}} \sim 7.8\right)$ as elucidated by tsunami runup north of Kronotsky Peninsula in southern to central Kamchatsky Bay. Some studies have characterized the subduction zone off Kronotsky Peninsula as either more locked or more smoothly slipping than surrounding areas and have placed the 1997 rupture south of this promontory. However, 1997 tsunami runup north of the peninsula, as evidenced by our mapping of tsunami deposits, requires the rupture to extend farther north. Previously reported runup (1997 tsunami) on Kronotsky Peninsula was no more than 2-3 m, but our studies indicate tsunami heights for at least $50 \mathrm{~km}$ north of Kronotsky Peninsula in Kamchatsky Bay, ranging from 3.4 to $9.5 \mathrm{~m}$ (average $6.1 \mathrm{~m}$ ), exceeding beach ridge heights of 5.3 to $8.3 \mathrm{~m}$ (average $7.1 \mathrm{~m}$ ). For the two 1923 tsunamis, we cannot distinguish among their deposits in southern to central Kamchatsky Bay, but the deposits are more extensive than the 1997 deposit. A reevaluation of the April 1923 historical tsunami suggests that its moment magnitude could be revised upward, and that the 1997 earthquake filled a gap between the two 1923 earthquake ruptures. Characterizing these historical earthquakes and tsunamis in turn contributes to interpreting the prehistoric record, which is necessary to evaluate recurrence intervals for such events. Deeper in time, the prehistoric record back to $\sim \mathrm{AD} 300$ in southern to central Kamchatsky Bay indicates that during this interval, there were no local events significantly larger than those of the
\end{abstract}

20th century. Together, the historic and prehistoric tsunami record suggests a more northerly location of the 1997 rupture compared to most other analyses, a revision of the size of the April 1923 earthquake, and agreement with previous work suggesting the northern KSZ ruptures in smaller sections than the southern KSZ. The final suggestion should be considered with caution, however, as we continue to learn that our historic and even prehistoric records of earthquakes and tsunamis are limited, in particular as applied to hazard analysis. This study is a contribution to our continued efforts to understand tectonic behavior around the northern Pacific and in subduction zones, in general.

\section{Introduction}

In this paper we intend to illustrate how tsunamis may inform interpretations of their earthquake sources. For example, by presenting previously unpublished tsunami-deposit data we show that the December 1997 Kamchatka tsunami requires a different earthquake source region than geophysically interpreted, a source that lies between prior historical events (in a seismic gap). This conclusion leads us to the question: do earthquakes in the northern part of the Kamchatka Subduction Zone (KSZ) characterize it as rupturing in shorter segments than in the southern part? We address this question, particularly for northern portion, by studying the history and the prehistory of tsunamis in this region. In conducting this analysis, we illustrate some of the strengths and limitations of reconstructing prehistoric tsunamis, even with strong age control from well-dated and well-mapped tephra. 


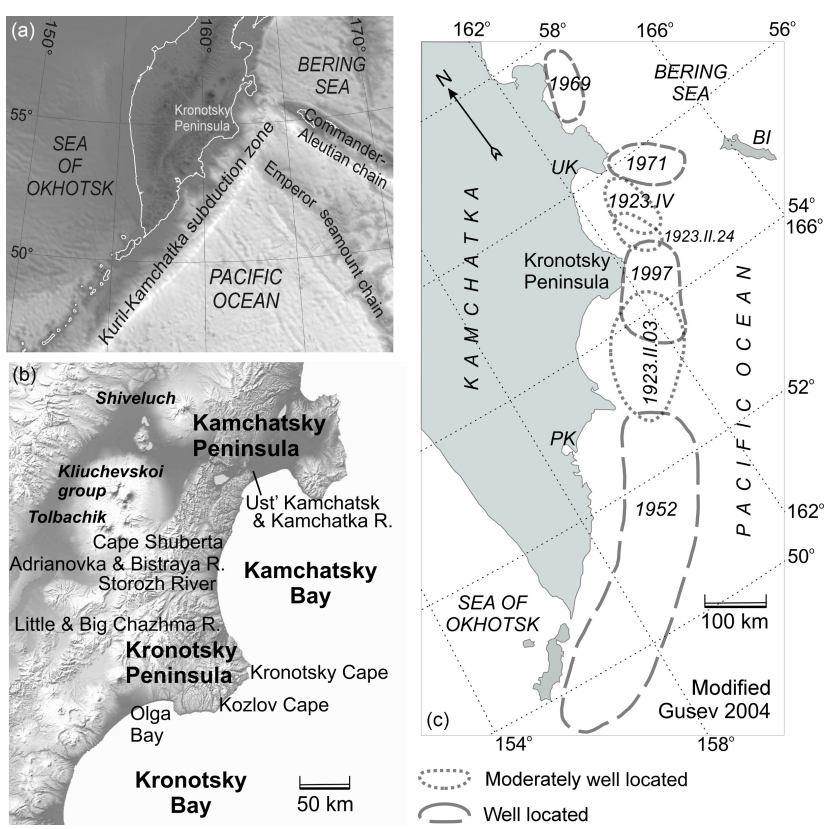

Figure 1. General tectonic setting and study locations. (a) Major topography of and bathymetric features around Kamchatka. (b) locations of sites mentioned in the text and tables. (c) Interpreted rupture locations of 20th century tsunamigenic (except 24 February 1923) earthquakes along the Kamchatka portion of the KurilKamchatka subduction zone (modified from Gusev, 2004, Fig. S1; Martin et al., 2008). The rupture area of the 1997 earthquake shown here is from Gusev (2004) and outlines the entire aftershock zone (Fig. 2). Tide-gage locations: PK, Petropavlovsk-Kamchatsky; UK Ust' Kamchatsk; BI, Bering Island.

Without post-tsunami or tsunami-deposit surveys, remote spots in the world may experience large events without a written record, as illustrated, for example, by references to the "modest" or "small" tsunami of the 15 December 2006 central Kuril Islands earthquake (Ammon et al., 2008; Liu, 2009). In fact this tsunami generated an average of $9.6 \mathrm{~m}$ runup over an along-rupture length of $390 \mathrm{~km}$ (MacInnes et al., 2009). The case we present herein of the 5 December 1997 tsunami following the $M_{\mathrm{w}}$ 7.7-7.9 Kronotsky earthquake (Figs. 1, 2), however, is even more complex historically, because there was a post-tsunami survey quickly following (Zayakin and Pinegina, 1998), though of limited extent. The local tide-gage record for this 1997 tsunami is also incomplete, and deep-water pressure recorders deployed at the time were not positioned to get distinctive recordings from a tsunami originating near Kronotsky Cape (Bourgeois and Titov, 2001). The earthquake and tsunami occurred in the dark of a December night in an area with no permanent settlements.

In the summer of 2000, we conducted a field survey for historical and paleotsunami deposits in the south Kamchatsky Bay (also called Kamchatskiy Gulf) (Fig. 1), north of Kronotsky Peninsula. We expected to find evidence for

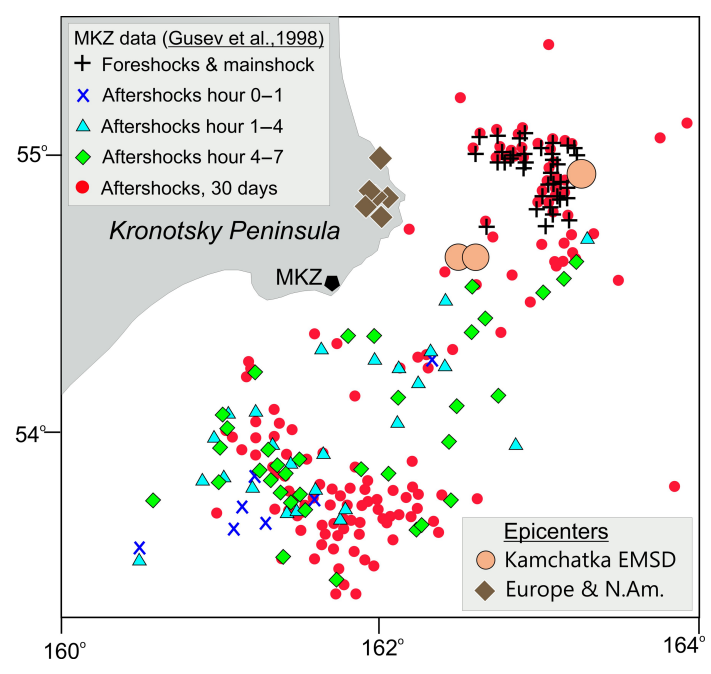

Figure 2. Foreshocks (3-5 December 1997), mainshock, and aftershocks of the 5 December 1997 Kronotsky earthquake (Gusev et al., 1998), including location of nearest seismic station, MKZ. Plotted foreshocks and MKZ aftershocks include only cases where $P$ and $S$ arrivals could be read from MKZ records. Locations of epicenters are from various analyses, both local and farfield as reported from the International Seismological Center (Supplement Table S2). Slavina et al. (2007) interpret the southwestern aftershock activity to be on a separate, transverse fault; Kuzin et al. (2007) also interpret the SW portion of the (extended) aftershock region to be a separate stress zone.

historical Kamchatka tsunamis such as 1923 (Table 1; Table S1), but not for 1997 Kronotsky because on the Kronotsky Peninsula, the post-tsunami survey found evidence of quite limited runup. Thus we were surprised to find a sand layer just at the surface, covered only by plant debris such as grass and leaves, distributed much as we have come to expect of tsunami deposits, and at elevations of $5 \mathrm{~m}$ or more above sea level. Although we were skeptical at first, we could find no alternative to explain the layer and its distribution other than a tsunami from the 1997 earthquake.

The implications of this case, where an earthquake was analyzed without full knowledge of its tsunami, are several. First, the fact that there was runup greater than that reported by a post-tsunami survey changes our view of the tsunami as well as of the earthquake. Further, the size of the tsunami, based on its deposits and a corroborating eyewitness account (acquired in 2001), helps constrain rupture characteristics of this earthquake. This constraint in turn leads to an interpretation of segmentation of the northern KSZ, and our interpretation that the tsunamigenic portion of this earthquake rupture occurred in a gap between the two 1923 tsunamigenic earthquakes.

This recent historical tsunami also helps us interpret earlier historical and prehistoric earthquakes and tsunamis along the northernmost part of the Kuril-Kamchatka subduction zone. Tsunamis originating from this region commonly have an 


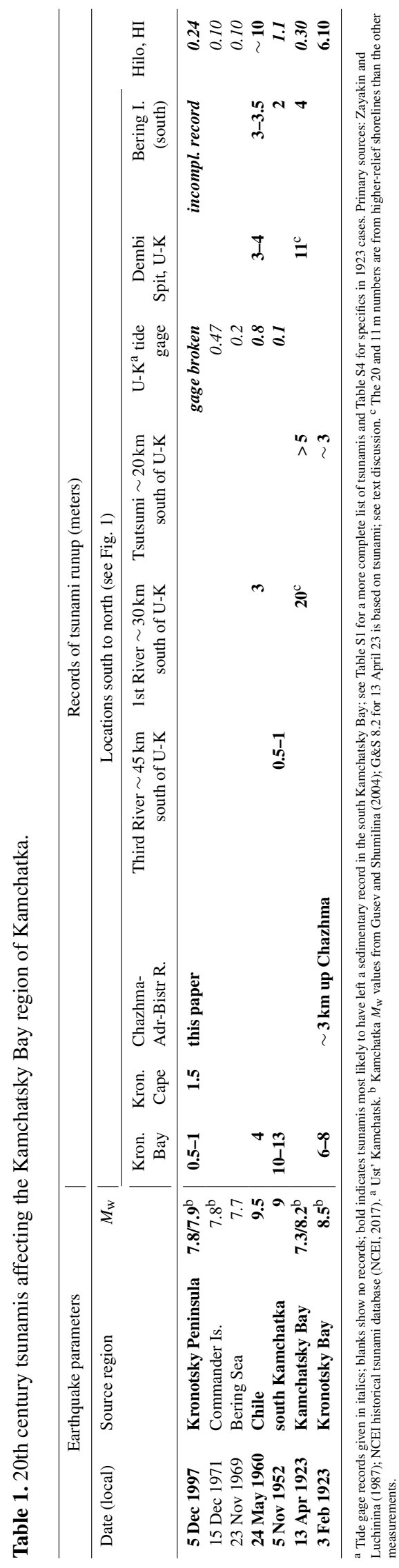

impact not only locally but also on Hawaii, as did the February 1923 tsunami, and in some cases even on the western coast of the Americas, as did the 2006 central Kuril Islands tsunami.

\section{Background}

\subsection{The 1997 Kronotsky earthquake}

On 5 December 1997 at 23:26:51 local time (11:26:51 UTC), a large earthquake $\left(M_{\mathrm{w}} 7.7-7.9\right.$; we use 7.8) shook the region of the Kronotsky Peninsula, Kamchatka, Russia (Figs. 1, 2; Gordeev et al., 1998). The earthquake was characterized by a typical foreshock-mainshock-aftershock sequence (Gusev et al., 1998; Fedotov et al., 1998; Balakina, 2000; Zobin and Levina, 2001; Kuzin et al., 2007; Slavina et al., 2007). Most studies of the earthquake calculate a moment magnitude of 7.8 for the energy released in the first 60-80 s of the main rupture (e.g., Zobin and Levina, 2001). Gusev and Shumilina (2004), in reassessing many Kamchatka earthquakes, assign $M_{\mathrm{W}} 7.9$ to Kronotsky 1997 . In addition to the mainshock, and using GPS measurements, Gordeev et al. (2001) calculate $M_{\mathrm{W}} 7.7$ for deformation in the pre-seismic halfmonth, and approximately $M_{\mathrm{w}} 7.9$ for post-seismic deformation; Bürgmann et al. (2001) calculate $M_{\mathrm{w}} 7.7$ of (postseismic) aseismic energy release in the 2 months following the mainshock, also based on GPS data.

The locations of the mainshock and of any slip concentration for this earthquake have not been well resolved, and with one early exception (Sohn, 1998), locators have not used tsunami data. Based on seismic data, the locations of foreshocks and the mainshock/epicenter (Fig. 2) are in the northern part of the interpreted rupture area. A number of analytical locations of the mainshock lie under the NE Kronotsky Peninsula (Fig. 2; Table S2). Some analyses interpret the rupture to have propagated NE to SW (Petukhin et al., 1998), deepening toward the SW. Gusev (2004) maps the entire aftershock zone as part of the 1997 event (Fig. 1). On the other hand, the linear zone of aftershocks in the SW (Fig. 2) has been interpreted to be a separate stress zone (Kuzin et al., 2007) potentially along a separate transverse fault (Slavina et al., 2007). In an analysis focused on GPS data, Bürgmann et al. (2001) place the majority of the primary rupture energy in the southern half of the aftershock zone.

\subsection{The recorded 1997 Kronotsky tsunami}

The most complete contemporary record of the 1997 Kronotsky tsunami is from far-field tide gages. Both proximal tide gages, in Ust' Kamchatsk and in Nikol'skoe (Bering Island) (Fig. 1), were not functioning when the tsunami arrived. The Petropavlovsk-Kamchatsky gage is very protected and shows a wave train with an amplitude of about $0.01 \mathrm{~m}$ (Zayakin and Pinegina, 1998). The tide gage at Nikol'skoe resumed recording after the first $10 \mathrm{~h}$ of the tsunami, with a few 
centimeters of amplitude remaining (Zayakin and Pinegina, 1998). The far-field tsunami had tide-gage amplitudes in Alaska/Aleutians and Hawaii in line with other tsunamis traveling to Hawaii from the Russian Far East (Table S3; Fig. S4). The tsunami was recorded on at least 12 tide gages, with the highest amplitude (half of wave height) of $0.3 \mathrm{~m}$ at Kahului, Maui, Hawaii (NCEI online database). Deep-water pressure sensors deployed at that time in the North Pacific were all in tsunami shadows for this tsunami source, and in all cases, the modeled and measured tsunami was within the noise level of the buoys (Bourgeois and Titov, 2001; no event page at http://nctr.pmel.noaa.gov/database_devel.html).

A truncated post-earthquake and tsunami survey by helicopter took place on 9 December 1997 (Leonov, 1998; Zayakin and Pinegina, 1998). The survey reached as far north as Kronotsky Cape on the Kronotsky Peninsula (Fig. 1) and found that the tsunami had not exceeded the unvegetated sandy beach. At this time, the beach was covered with a thin layer of ice and snow, which in places had been coated by the tsunami with a thin sand layer and elsewhere had been broken up by the tsunami (Fig. 3). The team did not have surveying equipment and estimated runup to be no more than $3 \mathrm{~m}$ (T. Pinegina notes), and the published report gave a maximum of $1-1.5 \mathrm{~m}$. The turnaround point in the survey was dictated by fuel and available daylight.

On 5 December 1997, two rangers were in a cabin near Big Chazhma River (Fig. 1); one of them was interviewed (in Petropavlovsk-Kamchatsky) by T. Pinegina on 19 April 2001. They felt the earthquake that night, and the next day, as was routine, they went via snowmobile to survey the northern coastal part of Kronotsky Nature Reserve, in the Little Chazhma River area. At the mouth of the Big Chazhma River, they saw jumbled ice and seaweed on the snow; a cabin on the south bank of the Little Chazhma River was partly wetted, and there was seaweed on the snow. Normally the rangers crossed the river near this cabin, but the river was a jumble of ice and they had to go some distance upstream in order to cross (on ice). On the other side, they could not continue north because there was water in the low spot between beach and hill (see Fig. 4, our profile 100).

Based on results of the post-tsunami survey (reported to Sohn by V. Gusiakov), Sohn (1998) analyzed the tsunami with regard to its earthquake source and concluded that the main rupture must have lain largely under land, in order to explain the low runup accompanying a moment magnitude the author calculated as $M_{\mathrm{w}}$ 7.7.

\subsection{Historical record of earthquakes and tsunamis affecting the field area}

The Kamchatka Peninsula has a short but rich historic record of large earthquakes and attendant tsunamis; herein we discuss only 20th century tsunamis originating in or having been recorded in the field region of Kamchatsky Bay (Table 1). In addition to locally originated tsunamis, Kamchatka is vul-
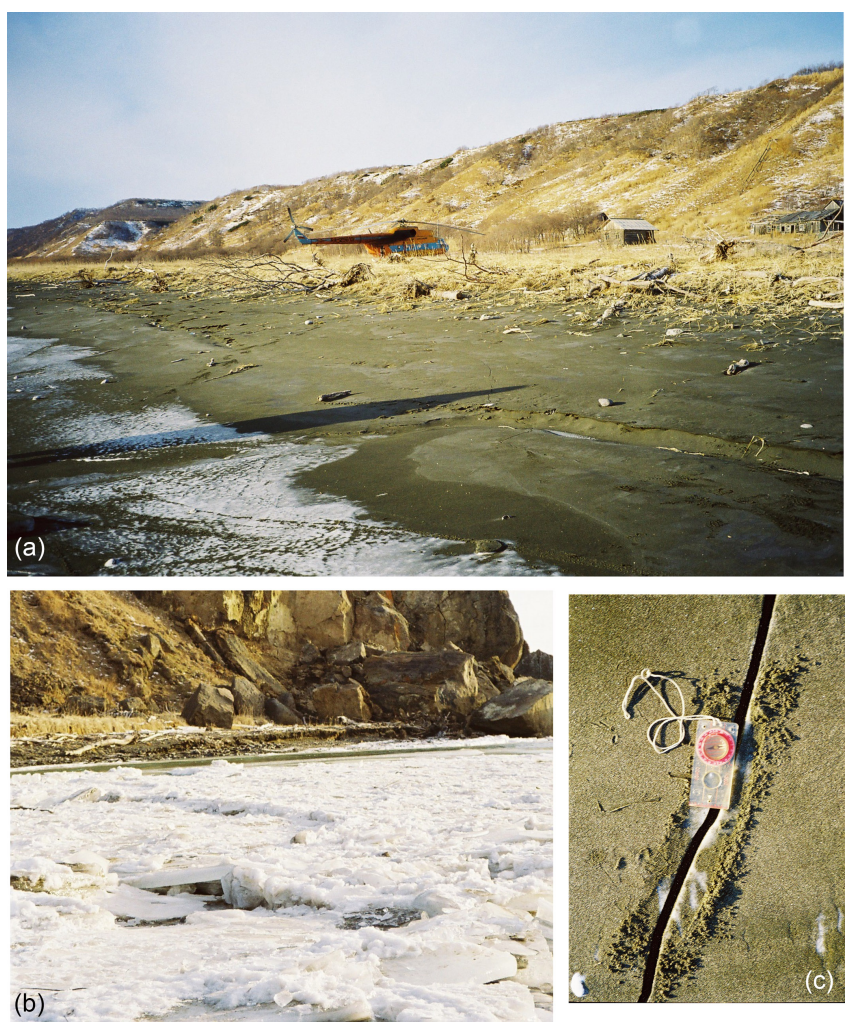

Figure 3. Photos taken by T. Pinegina on 9 December 1997 near Kronotsky Cape (location in Fig. 1). For an additional photo and sketch for context, see Fig. S3. (a) With helicopter for scale: the tsunami deposited sand on the snow up to about the line of grassy vegetation at the back of the beach (see detail, lower right photo); white zone in foreground is sea foam. (b) Ice and snow broken up by the tsunami (excerpted from photo in Fig. S3). (c) With compass for scale: detail of tsunami-deposited sand above snow that covered the beach, scraped by hand away from a crack in the snow/ice which is interpreted to have been made during an aftershock.

nerable to tsunamis from Chile, less so from Peru, and minimally from Japan, Alaska/Aleutians, and Central America, due to directivity (e.g., see Table S1). Based on scant records (Table 1), the 1960 Chile tsunami likely reached elevations of 3-5 m above sea level along Kamchatsky Bay (Fig. 1), on the order of 2 times higher than the 1952 southern Kamchatka tsunami in this bay (Table 1)

The largest documented local tsunamis from earthquakes near Kronotsky Peninsula (Fig. 1; Table 1) are two from 1923, both having local as well as far-field records (Table S4); both may have affected south-central Kamchatsky Bay. There was also a 24 February $1923 M_{\mathrm{w}} 7.6$ earthquake in this area (Fig. 1; Gusev, 2004); however, it has no historical tsunami record in the near or farfield. The $M_{\mathrm{W}} 8.01917$ earthquake along the Steller fracture zone (Fig. S1) also did not produce a recorded tsunami. The 3 February 1923 Kronotsky Bay earthquake $\left(M_{\mathrm{w}} 8.5\right)$ was located south of Kronotsky Cape (Fig. 1), and its tsunami was large $(6-8 \mathrm{~m})$ in 


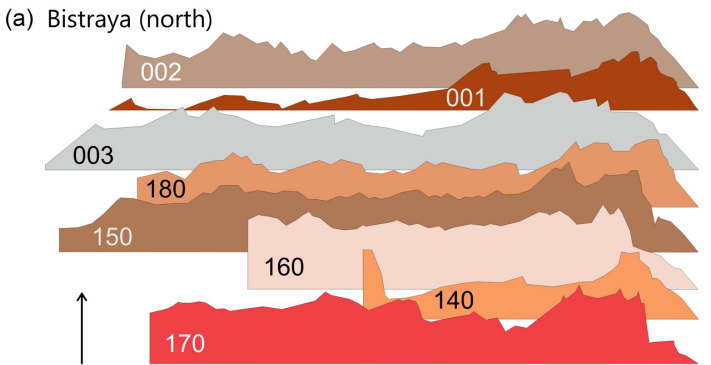

(b) Storozh

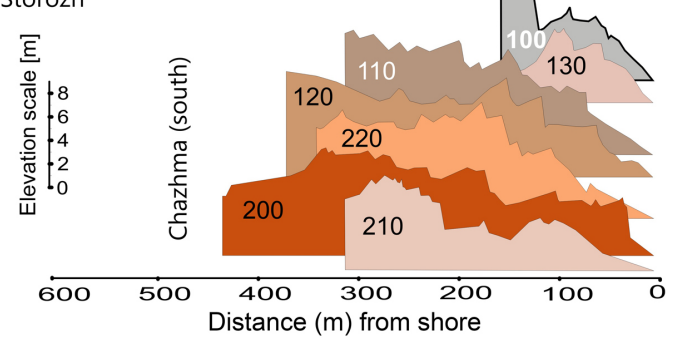

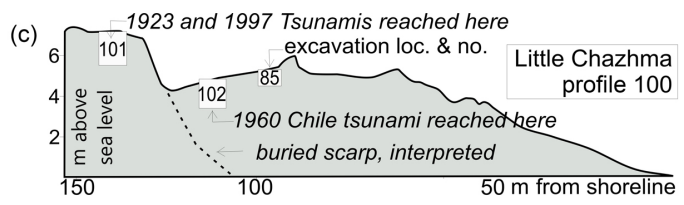

(d)

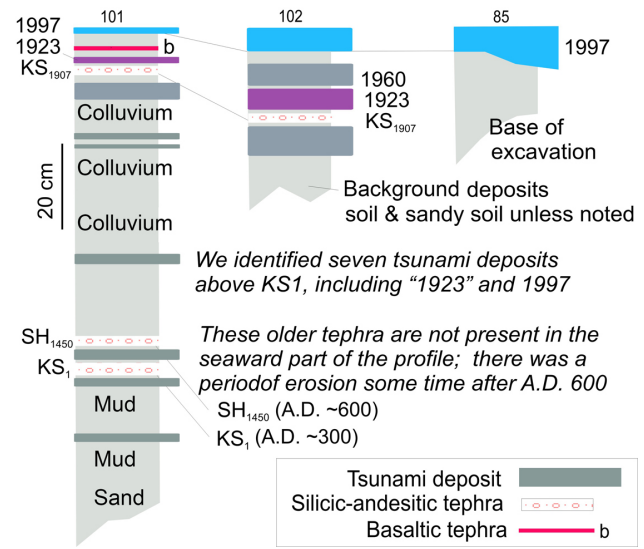

Figure 4. (a, b) Topographic profiles measured in southern Kamchatsky Bay (locations in Fig. 1, arranged from south (b) to north (a), except 001 and 002 reversed to reveal topography. Distances and elevations are measured from 0 at the water line (lower right corner of each profile), corrected to high tide. (c, d) Chazhma profile 100 used as a key to collected profile data and interpretations (interpretations in italics); background deposits are soil or sandy soil, unless otherwise noted.

Kronotsky Bay (Table 1), decreasing northward; a sled team in the area during and after the earthquake reported a coastal ice rampart being pushed about $3 \mathrm{~km}$ upstream on the (Big?) Chazhma River, north of Kronotsky Cape. The 13 April 1923 north Kamchatsky Bay earthquake $\left(M_{\mathrm{w}} 7.3\right.$ in NCEI catalogue; 14 April local time) generated a very high tsunami in north to north-central Kamchatsky Bay (Tables 1, S1), with large (largest; naibolshii) effects south to Cape Shubert in south-central Kamchatsky Bay (Fig. 1; Troshin and Diaghilev, 1926). Based on tsunami amplitudes, Gusev and Shumilina (2004) suggested this April 1923 earthquake had a moment magnitude of 8.2 (Table S1, Fig. S2). In sum, the February and April tsunami runup was large south and north (respectively) of our field area, decreasing toward that field area.

The record of earthquakes and tsunamis on Kamchatka prior to the 20th century is spotty but improving (Zayakin and Luchinina, 1987; Godzikovskaya, 2010). Earthquakes on 17 May 1841 and 17 October 1737 originated in the region of the 1952 south Kamchatka great earthquake, so they likely did not have significant effects in (southern) Kamchatsky Bay (see Table 1, 1952 runup). Other tsunamis that may have affected southern Kamchatsky Bay are an autumn 1849 tsunamigenic earthquake in the vicinity of the Komandorsky Islands (Godzikovskaya, 2010) and a 1791 event with an intriguing account of having affected the mouth of the Kamchatka River (Ust' Kamchatsk), reported to reach $7 \mathrm{~km}$ upstream (Zayakin and Luchinina, 1987).

\section{Methods}

We measured 15 topographic profiles (Fig. 4) perpendicular to the shoreline along the coast of southern to central Kamchatsky Bay (Figs. 1, S2), and made 117 hand-dug excavations along these profiles in order to document historical and paleotsunami deposits. We used a surveying rod with a transit level (hand level and tape for profile 001 and upper part of profile 120; methods as in Bourgeois et al., 2006). We usually excavated to $0.5-1 \mathrm{~m}$ deeper than the lowest preserved tephra overlying clean sand (not exhibiting soil weathering).

It is well established that tsunamis create sedimentary deposits as they flood a coastal plain with turbulent, turbid water, and there are means to distinguish tsunami deposits from those of floods, storms, and wind. The general characterization of a tsunami deposit in sandy coastal systems is a sand sheet which typically thins and fines landward, following topography and commonly thickening in swales (Bourgeois, 2009). Many factors, from sediment availability to coastal topography and surface roughness to the velocity profile of incoming and outgoing waves, play a role in sedimentation. Kamchatka field sites are primarily sandy, vegetated coastal plains and associated peat marshes, where shoreline availability of sand and onshore vegetative cover maximize the likelihood of generating and preserving tsunami deposits. (Many historical Kamchatka tsunamis have occurred during winter snow cover; deposits would have been "let down" onto a vegetative mat as the snow melted.) In these settings, river flood deposits are muddy (not clean sand), and eolian deposits are rare, not sheetlike, and consistently fine-grained; 


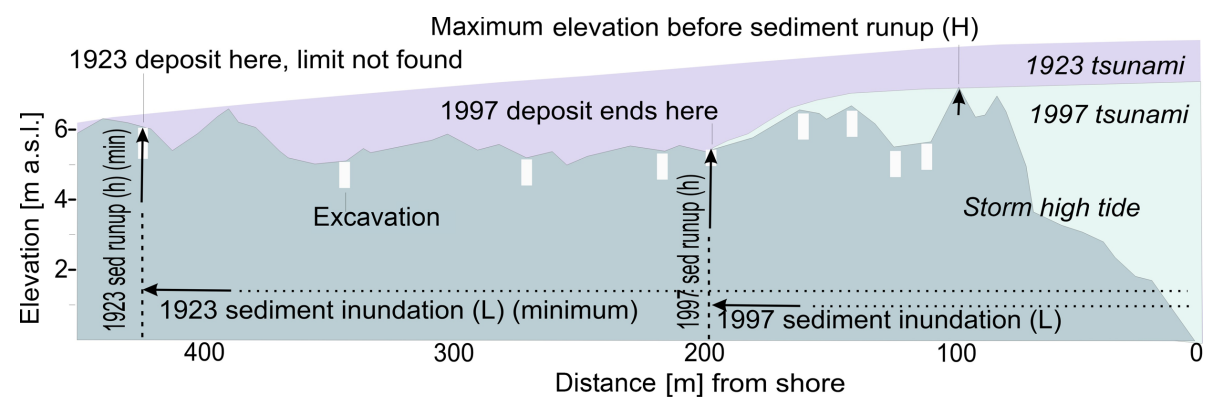

Figure 5. Terminology for sediment runup and sediment inundation, and interpretation of deposits from 1997 and 1923 , using example of an actual profile (Storozh 160; vertical exaggeration $\sim 10$ ). Near the shoreline on this profile, both tsunamis had to exceed a point $(H)$ higher than "sediment runup" $(h)$ and, although the minimum sediment runup for 1923 is not much greater than for 1997, 1923 was likely higher to have generated greater inundation, which is also related to tsunami wave length. Note that a 2-D interpretation of (orthogonal) tsunami flow over this and most study profiles is justified by the lateral continuity of ridges. In a few cases (discussed in the text), the tsunami may have reached a runup/inundation point via a lower, more circuitous route. Distances and elevations are from surveying.

storm waves and storm surge at these latitudes rarely exceed elevations and particularly distances of our surveyed profiles (see Bourgeois et al., 2006).

We use three measurements to characterize tsunamis via their deposits (Fig. 5): sediment inundation $(L)$, sediment runup $(h)$, and maximum height seaward of a deposit on a given profile $(H)$. The maximum distance inland of a tsunami deposit (sediment inundation, Fig. 5) and the deposit's elevation at sediment inundation (sediment runup, Fig. 5) represent minimum estimates of tsunami extent for several reasons: tsunami deposits can only be more limited (not more extensive) than water runup and inundation, the final limit of a deposit is not always located in the field on any given profile, and thin deposits may not be identified or preserved.

Primary age control in excavations is provided by dated regional and local marker tephra layers (Table 2), which in general have been well studied on Kamchatka (e.g., Braitseva et al., 1997), although tephra in the southern Kamchatsky Bay area had not previously been examined. Based on our own and other earlier work, as well as on more recently published isopach maps (Kyle et al., 2011; Ponomareva et al., 2017), the three most consistently present layers in the sections are $\mathrm{KSht}_{3}$ (AD 1907 - we use $\mathrm{KS}_{1907}$ ) - most useful for studying the historical record, $\mathrm{SH}_{1450}(\sim \mathrm{AD} 600)$, and $\mathrm{KS}_{1}$ ( $\left.\sim \mathrm{AD} 300\right)$, the latter used as the lower boundary for our tsunami statistics. A fourth marker, $\mathrm{SH}_{2}(\sim \mathrm{AD} 1130)$, is commonly present in more northerly profiles. Recent work around Shiveluch volcano and Kamchatsky Peninsula (Fig. 1) has led to redesignation of Shiveluch tephras and to more definitive model ages of these tephra (Ponomareva et al., 2017). In addition to the silicic marker tephra (Table 2), there are local basaltic andesitic tephra layers, which can be from Kliuchevskoi, Bezymianny, Tolbachik, or Gamchen volcanoes; we used these tephra only as local field guides. In the northernmost of our profiles, a historic ash from Bezymianny 1955 (the year before the 1956 paroxysmal eruption) is locally present and used as a factor in distinguishing Chile 1960 tsunami deposits from those of Kamchatka 1952.

For the prehistoric record of tsunami runup and inundation, topographic profiles are not necessarily the same as in the recent past and thus must be reconstructed to account for succeeding topographic changes in elevation and distance along the profile. While we cannot typically reconstruct profiles that have been changed by erosion, we can reconstruct profile progradation (building seaward), which affects profile width. Our method uses preserved tephra as discussed, for example, in Pinegina et al. (2013) and MacInnes et al. (2016), as summarized in Fig. S5. Changes in elevation relative to sea level are quantified by determining the age and elevation of the lowest former soil horizon above marine sand in any excavation (Fig. S5; as in Pinegina et al., 2013). For the case herein, reconstructing less than 2000 years of coastal history, our calculated changes in relative sea level are due to active tectonics, not eustatic or regional sea-level fluctuation.

\subsection{Field localities}

The southern field site (Fig. 1) which we call "Chazhma" (Fig. 4) is a narrow strip ( $\sim 400 \mathrm{~m}$ wide or less) of Holocene accumulative coastline along a rugged coast just north of the Kronotsky Peninsula. The two profiles near river mouths (Chazhma 210 and Chazhma 130; Fig. 4) maintain lower elevations $(<4 \mathrm{~m})$ over much of their distance, though both reach elevations of more than $6 \mathrm{~m}$ above sea level. The other five profiles rise, typically in sharp steps indicative of Holocene uplift events (as in Pinegina et al., 2013), reaching typical maximum levels of 8-10 m (Fig. 4). Net uplift on these profiles is consistent with longer-term uplift of Pleistocene terraces on the Kronotsky Peninsula (Melekestsev et al., 1974).

The northern field site which we call "Storozh", extending north to the Bystraya River (Figs. 1,4), is a broader strip (typically $600 \mathrm{~m}$ wide) of Holocene accumulative coastal plain 
Table 2. Marker tephra layers $<2000$ years old in shoreline profile sections, southern Kamchatsky Bay ${ }^{\mathrm{a}}$.

\begin{tabular}{|c|c|c|c|c|c|c|}
\hline $\begin{array}{l}\text { Code } \\
\text { field/classic }\end{array}$ & $\begin{array}{l}\text { Code } \\
\text { new }^{\mathrm{a}}\end{array}$ & Source volcano & $\begin{array}{l}\text { Modeled age } \\
(\text { years BP) }\end{array}$ & $\begin{array}{l}\text { Assigned age } \\
\text { (calendar year) }\end{array}$ & Field description & Field thickness \\
\hline $\mathrm{KSht}_{3}^{\mathrm{b}}$ & $\mathrm{KSht}_{3}$ & Ksudach & Historical & AD 1907 & Light to medium gray, fine to very fine sand & $0.5-2 \mathrm{~cm}$ \\
\hline $\mathrm{SH}_{2}$ & SH\#6 & Shiveluch & $817+59 /-57$ & AD 1134 & $\begin{array}{l}\text { White (faint gray, yellow white), fs-vfs, } \\
\text { has pumice }\end{array}$ & $0.5-1 \mathrm{~cm}$; distinct toward north \\
\hline $\mathrm{SH}_{1450}$ & SH\#12 & Shiveluch & $1356+52 /-45$ & AD 596 & $\begin{array}{l}\text { Pale yellow, yellow gray, lt gray, vfs-ms, } \\
\text { salt \& pepper - grainy }\end{array}$ & $1-2.5 \mathrm{~cm}$; typically $1-2 \mathrm{~cm}$ \\
\hline $\mathrm{KS}_{1}$ & $\mathrm{KS}_{1}$ & Ksudach & $1651+54 /-61$ & AD 298 & $\begin{array}{l}\text { Lt brown, beige, "coffee cream"; } \\
\text { thin gray cap; si-vfs }\end{array}$ & $1-3 \mathrm{~cm}$; usually not $>2 \mathrm{~cm}$ \\
\hline
\end{tabular}

${ }^{a}$ Ponomareva et al. (2017). ${ }^{\text {b }}$ Braitseva et al. (1997); in our text, we supplant KSht 3 with KS 1907 .

associated with active and drowned river mouths. Two of these profiles (140, 001; Fig. 4) drop in elevation behind one or more beach ridges. The other seven profiles are typified by a series of beach ridges, of which the seaward ridges are higher, reaching typically 6-7 m, with an average elevation of the profile in the range of 4-6 m (Fig. 4). Such profiles indicate minor subsidence or no vertical change in the late Holocene.

\section{Results - 20th century tsunami deposits}

In field season AD 2000, the sand we interpret to have been deposited by the 1997 Kronotsky tsunami formed a sheet-like layer at the surface, buried only by grass, leaves, and other dead vegetation, in general decreasing landward in thickness and grain size. The deposit we interpret to be "1923" (from one or both of two tsunamis in 1923) lies above the marker tephra $\mathrm{KS}_{1907}$ with less soil thickness between $\mathrm{KS}_{1907}$ and "1923" than between the top of "1923" and the base of the modern turf. Our interpretation of "1923" as well as a rare sand layer between "1923" and 1997, which we assign to the 1960 Chile tsunami, is discussed below.

Using identified and mapped tsunami deposits, we calculate minimum sediment runup and inundation on each of the 15 profiles (Table 3, Fig. 6), correcting to high tide from tide at the time of survey. The 1997 tsunami occurred just after high tide; in all cases, using a high tide datum gives us minimum runup values. We determine minimum sediment runup $(h)$ by the presence or absence of distinct 1997 and "1923" deposits on each profile. We distinguish between profiles where the farthest landward excavation still contains the 1997 or " 1923 " deposit and ones that do not. If no deposit is present in one or more excavations landward of ones with a deposit, the limit of sediment inundation $(L)$ occurs within the measured profile (Fig. 5, example of 1997) and actual tsunami runup is estimated from sediment runup. For profiles where a particular tsunami deposit extends beyond all excavations (Fig. 5, example of 1923), the actual size of the tsunami could be, in some cases, significantly greater than our sediment runup and inundation minima. We also report the maximum height the tsunami had to exceed $(H)$ as it traveled along a profile (across the accumulative marine terrace).
In a few cases, the farthest inland excavation was at a low elevation that could have been reached via the river rather than over the profile (Table 3, Fig. 6), although the deposits observed were not muddy. Note that maximum elevations and inundation distances are affected by elevations and distances along actual profiles (Fig. 4); e.g., a profile cannot record sediment runup higher than its maximum elevation, and a short, steep profile will record shorter sediment inundation distances.

\subsection{7 tsunami}

Sediment runup data (Table 3, Fig. 6) indicate that in southern to central Kamchatsky Bay, the 1997 Kronotsky tsunami ran up as much as $9.5 \mathrm{~m}$, averaging $6.1 \mathrm{~m}$, with moderate inundation distances of $100-300 \mathrm{~m}$. The general pattern over about $100 \mathrm{~km}$ of coastline, including post-tsunami survey observations on Kronotsky Peninsula itself, is relatively smooth, and we also expect based on the pattern that there was run up north of our northernmost profile (Fig. 6), but north-central Kamchatsky Bay comprises sea cliffs, not coastal plain. The maximum elevation reached by the tsunami deposit is higher on southern (Chazhma) profiles. However, lower runup numbers on northern profiles may be an artefact of their lower elevations (Fig. 4); inundation distances are greater on these profiles (Table 3). On some profiles the 1997 deposit is absent.

\subsection{3 tsunamis}

Sediment runup and inundation data for " 1923 " indicate that this tsunami (or tsunamis) was larger than 1997 in the region of our profiles. The deposit we interpret as from " 1923 " is usually thicker and more extensive, and never less extensive, than the deposit from 1997 (see Figs. 5, 7, 8, 9). The "1923" deposit is present on all measured profiles whereas the 1997 deposit is missing on six (Table 3, Fig. 6). Only on profiles where the sediment limit was not found (e.g., 100), or where profiles dropped to low elevations at their landward extent (001, 180, 160, 140, 100, 130, 210) were "1923" deposits at similar or lower elevations than 1997; in many of these cases $(001,180,160,130)$, inundation distances for "1923" were longer. Even in the few cases where our field locations 
Table 3. Sediment runup and sediment inundation for historical tsunamis above $\mathrm{KS}_{1907}$, southern-central Kamchatsky Bay.

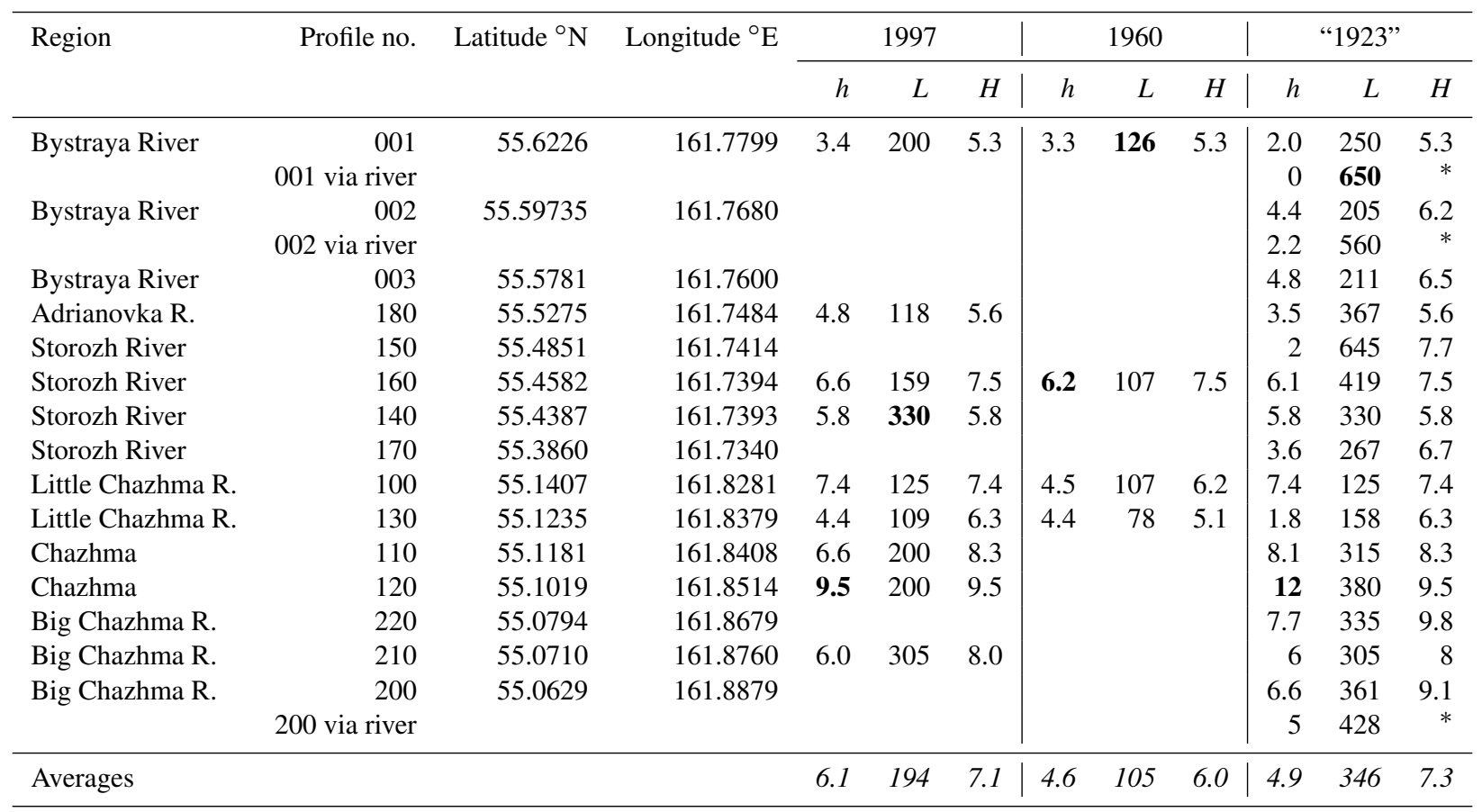

$h$ : elevation of excavation, meters above sea level (m a.s.l.) high tide, equals "sediment runup" (maxima in bold). $L$ : distance from the shoreline (m), equals "sediment inundation" (maxima in bold). $H$ : highest elevation (m a.s.l), between shoreline and excavation (as in Figure 5); likely exceeded where there is a sand deposit (max. in bold). *If the tsunami reached a low inland point via the river (indeterminate), $H$ from the profile is not relevant.

did not distinguish 1997 from "1923" by sediment runup or inundation (e.g., Storozh 140, Fig. 9), the "1923" deposit was coarser and/or thicker than 1997.

\subsection{Chile 1960 deposit}

Between "1923" and 1997 deposits on a few profiles (Table 3), there is a thin, patchy and less extensive deposit which we attribute to the 1960 Chile tsunami (e.g., Fig. 4, right). We favor 1960 Chile over 1952 Kamchatka for two reasons. First, the 1960 tsunami was larger than 1952 in the Kamchatsky Bay region (Table 1); the more locally generated 1952 tsunami dies off in amplitude along the strike of the rupture (MacInnes et al., 2010), whereas the Chilean tsunami on Kamchatka is little affected by latitude (Zayakin and Luchinina, 1987). Second, supporting the 1960 interpretation, in one excavation on profile 001 , this intermediate tsunami deposit lies above the Bezymianny 1955 tephra layer (Fig. 7).

\subsection{Historical tsunami deposit close below $\mathrm{KS}_{1907}$}

In many excavations (e.g., profile 100 in Fig. 4, profile 110 in Fig. 8), there is a tsunami deposit within a few centimeters of the base of $\mathrm{KS}_{1907}$ and which is comparable to 1997 and "1923" in thickness and extent. Although pre-1907 sedimentation rates are difficult to determine this tsunami deposit must fall within the historical period, which extends back to 1737 . However, the more complete historical records are from southern Kamchatka, and records from the second half of the 19th century are particularly spotty (Gusev and Shumilina, 2004). Thus there is no known historical event we can assign to this deposit; optically stimulated luminescence (OSL) dating might help in interpreting this deposit.

\section{Discussion - 1997 and "1923" deposits}

\subsection{7 tsunami}

Our observations are consistent with 1997 being a seismogenic tsunami source with significant rupture energy expended in the northern portion of the zone of aftershocks. The extensive and relatively smooth distribution of runup (Table 3; Fig. 6) and the ratio of maximum runup to distance over which the tsunami had significant runup (on the order of $10^{-5}$ ) indicate that this tsunami was typical of a seismogenic source rather than a landslide source (see Okal and Synolakis, 2004). The far-field tide-gage records (e.g., Hilo, Table 1) are also indicative of a broad rather than a point source. Given that the post-tsunami survey reported runup that did not exceed the beach on the Kronotsky Peninsula and that the deposits we mapped north of the peninsula are from the 1997 tsunami, any source model must explain the low ("water") runup on Kronotsky Peninsula and relatively high ("sediment") runup north of this peninsula (Fig 6). Sourceregion models by Bürgmann et al. (2001) and Llenos and 


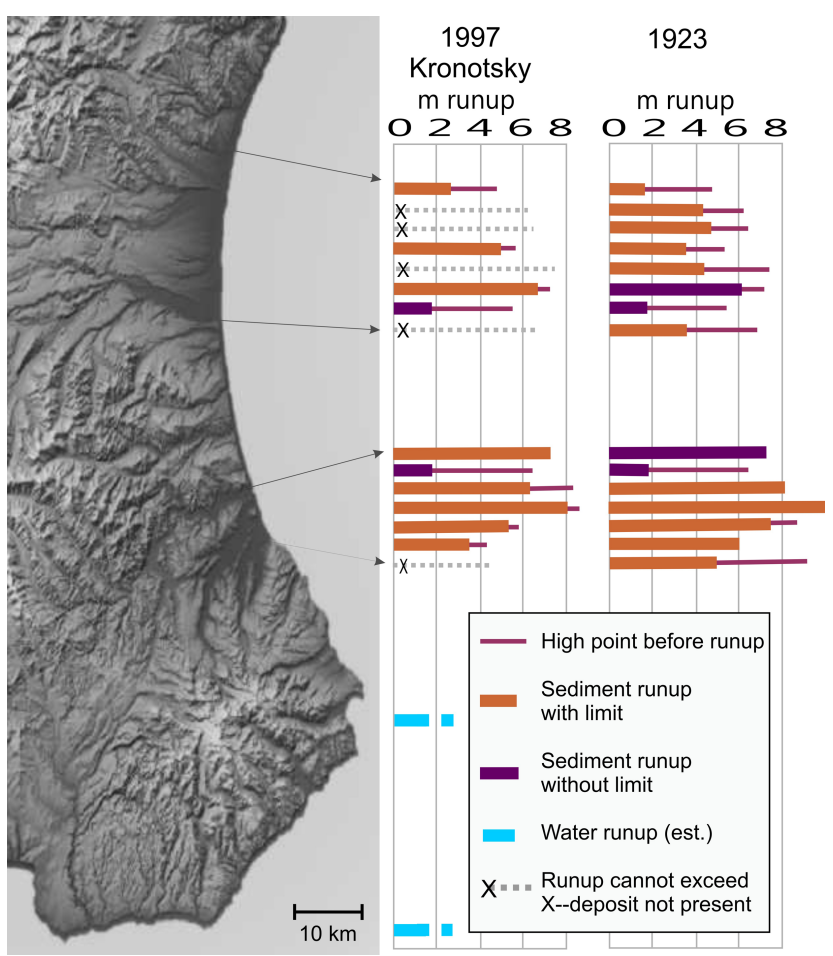

Figure 6. Water runup (Zayakin and Pinegina, 1998) and sediment runup (this paper, Table 3) for the 1997 Kronotsky tsunami on and north of the Kronotsky Peninsula, southern Kamchatsky Bay (locations in Fig. 1; also see Fig. S2). Water runup was not measured with instruments but was estimated; tsunami did not exceed the unvegetated beach (e.g., Fig. 3); it could have been somewhat higher than reported, shown on this figure by dashed blue line. Sediment runup is also illustrated for the tsunami deposit closely above $\mathrm{KS}_{1907}$, which we interpret as from 1923 February or April (see text discussion). Sediment inundation is given in Table 3, as well as latitudes and longitudes for the 15 profiles. Figures 4 and 5 illustrate methods and terminology.

McGuire (2007), for example, do not include the northern aftershock area, and such models have been used to interpret Kamchatka subduction-zone behavior (e.g., Song and Simons, 2003; Bürgmann et al., 2005; Llenos and McGuire, 2007; Bassett and Watts, 2015). On the other hand, source regions by Gusev et al. (1998), Gusev (2004), and Levina et al. (2013) tend to include the entire aftershock zone, overlapping February 1923 in the south but also filling the gap between February 1923 and April 1923 (Fig. S1), which might not be consistent with the tsunami data. Slavina et al. (2007) interpret the southwestern aftershock activity (Fig. 2) to be on a separate, transverse fault, and Kuzin et al. (2007) interpret the SW portion of the (extended) aftershock region to be a separate stress zone, interpretations more consistent with tsunami data. Zobin and Levina (2001) favor most mainshock energy being generated in the middle zone defined by fewer aftershocks (see Fig. 2), but this region is in shallower water, less conducive to tsunami genesis. A recently published finite-fault model resolves to most slip being under the Kronotsky Peninsula, with most energy release focused in the north (Hayes, 2017; https://earthquake.usgs.gov/ earthquakes/eventpage/usp0008btk\#finite-fault). As with the Sohn (1998) analysis, the Hayes (2017) model cannot explain the 1997 tsunami runup because the rupture is mostly under the Kronotsky Peninsula. Shifting this pattern of deformation eastward could resolve the discrepancy.

\subsection{3 tsunamis}

There are reasons to favor either or both the 3 February 1923 and 13 April 1923 Kamchatka tsunamis as the generator(s) of the deposit above $\mathrm{KS}_{1907}$ that we identify as "1923" (e.g., Figs. 7, 8, 9). Given what is known (Table 1), south-central Kamchatsky Bay is the place most likely to have comparable runups from each. Both tsunamis have a record in Hilo, but one is runup and the other tide-gage amplitude. There is no case on Kamchatka of a pair of similarly measured records from the same locality with which to compare the two tsunamis, with the exception of observations that the April tsunami generated more damage at the Tsutsumi fish plant southeast of Ust' Kamchatsk (Table S4). The 3 February tsunami was larger in most catalogued locations (Table S4) but apparently smaller than April 1923 in north Kamchatsky Bay. The two 1923 tsunamis both occurred while the ground would have been snow covered so that following snowmelt, it would be nearly impossible to distinguish two different deposits. The source regions of the two $1923 \mathrm{Kam}-$ chatka tsunamis have been mapped (Fig. 1), but they are not easy to constrain in detail other than saying that the February earthquake was south of Kronotsky Peninsula and the April earthquake north of it (Fig. 1). The February earthquake has been catalogued as $M_{\mathrm{w}} 8.3-8.5$ (ISC event 911271; NCEI) and the April earthquake as $M_{\mathrm{w}}$ 7.1-7.3 (ISC event 911331; NCEI), but the local and far-field tsunami runup for April 1923 suggests it may have been significantly larger (Gusev and Shumilina, 2004); based on its tsunami, Gusev suggests $M_{\mathrm{W}} 8.2$ for the April earthquake. A moment magnitude around 7.8-8.0 for the April earthquake would be more consistent with its tide-gage amplitude in Hilo (Fig. S2).

\section{Tsunami deposits pre-20th century back to $\mathrm{KS}_{1}$ ( AD 300)}

Goals in reconstructing paleotsunami history include both scientific and practical objectives. Scientifically, southern Kamchatsky Bay paleotsunamis can help us see patterns of subduction-zone behavior. Are the historical tsunamis (and their generating earthquakes) comparable to events in the past? What is the "typical" event and what are the rupture patterns of the northern Kamchatka subduction zone? Practically, these questions apply also to probabilistic hazard anal- 


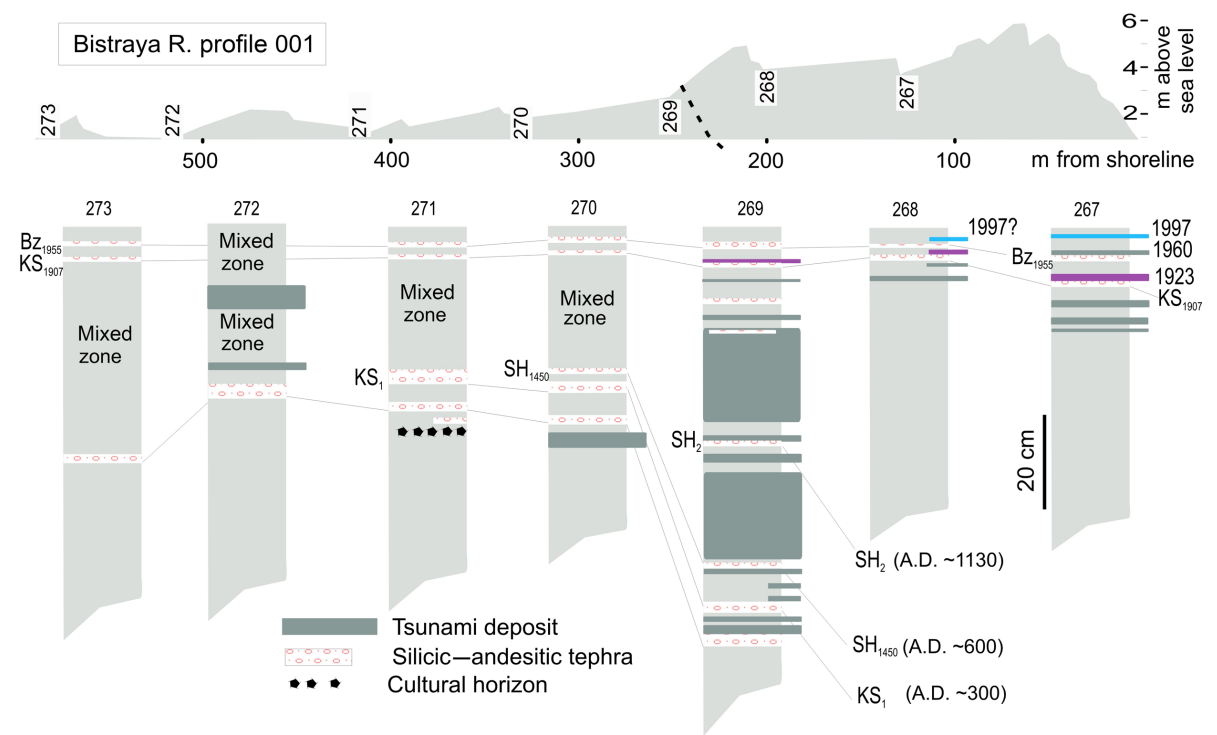

Figure 7. Northernmost profile, southern Kamchatsky Bay (Fig. 1 location; more extensive key in Fig. 4; tephra and tsunami deposits that are shown as narrower bands, e.g., 1997 in excavation 268, indicate thin, patchy deposits). This profile shows evidence of subsidence through time - the landward part of the profile is lower. This lower profile has been subjected to river erosion - the "mixed zone" is mostly fluvial sediment containing clasts of older material. Excavations with this mixed zone (273 to 270) all contain a tephra older than $\mathrm{KS}_{1}$, indicating that older strata are preserved below the reworked material. In this profile, there is an ash layer from the 1955 eruption of Bezymianny, a year before its major eruption. With this tephra present, we can assign the tsunami deposit above (in excavation 267) to Chile 1960 rather than to Kamchatka 1952.

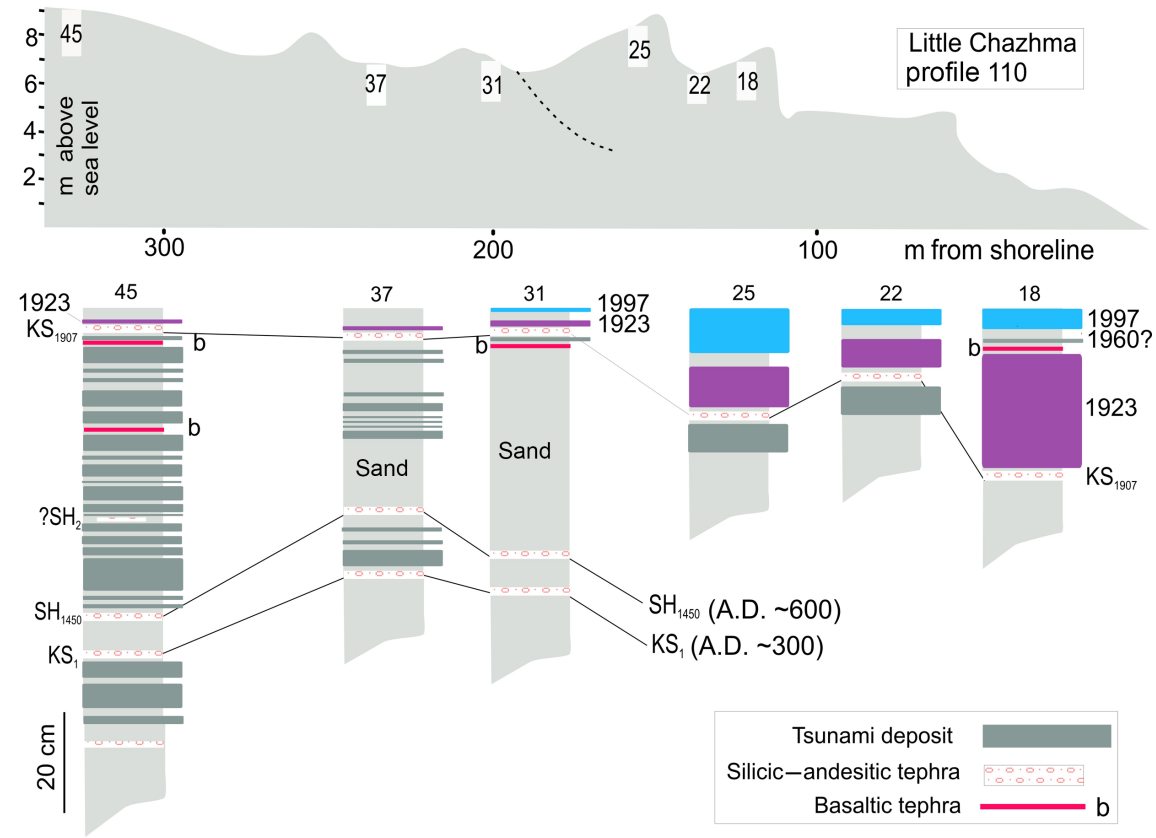

Figure 8. Profile 110, Chazhma area (Fig. 1 location; more extensive key in Fig. 4). This profile has been uplifted through time - the landward part of the profile is higher. Excavation 45 contains many tsunami sand layers currently at high elevation, which when reconstructed were lower (Fig. S5). In excavations 37 and 31, some of the section was too sandy (not enough soil development) to distinguish individual sand layers. The profile shows the distribution of 20th century deposits, as well as a tsunami deposit very close below KS 1907 . The 1923 tsunami(s) reached the highest point shown on this profile, whereas 1997 and "below $\mathrm{KS}_{1907}$ " were smaller. The deposit we tentatively assigned to Chile 1960 on this profile is not included in Table 3 because the deposit was not well preserved; it is higher than any other excavation containing a deposit we attribute to Chile 1960. 
(a)

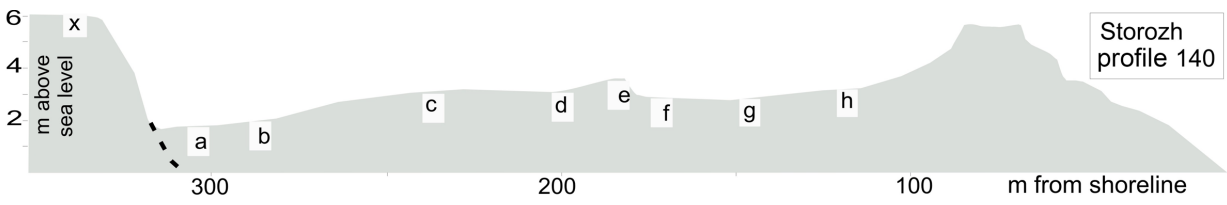

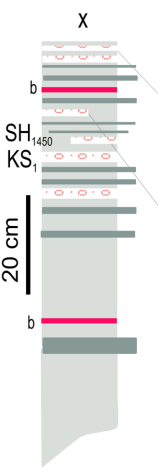

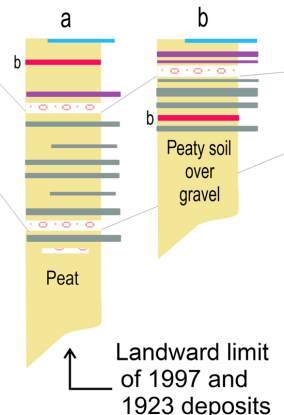

(b)

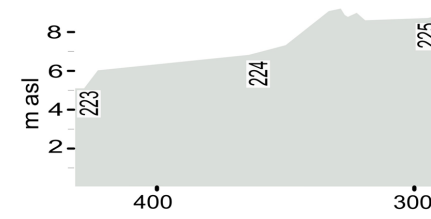

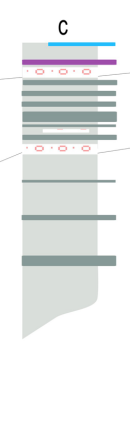

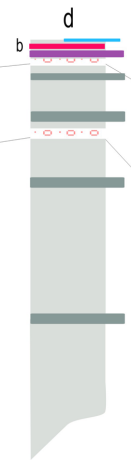

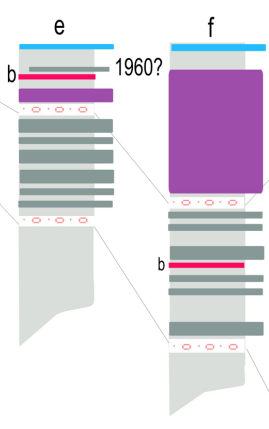

$\mathrm{SH}_{2}$ (A.D. 1130)

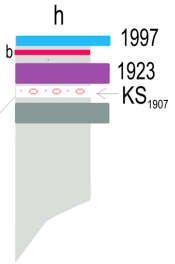

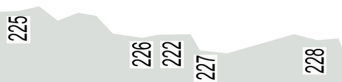

Chazhma profile 200
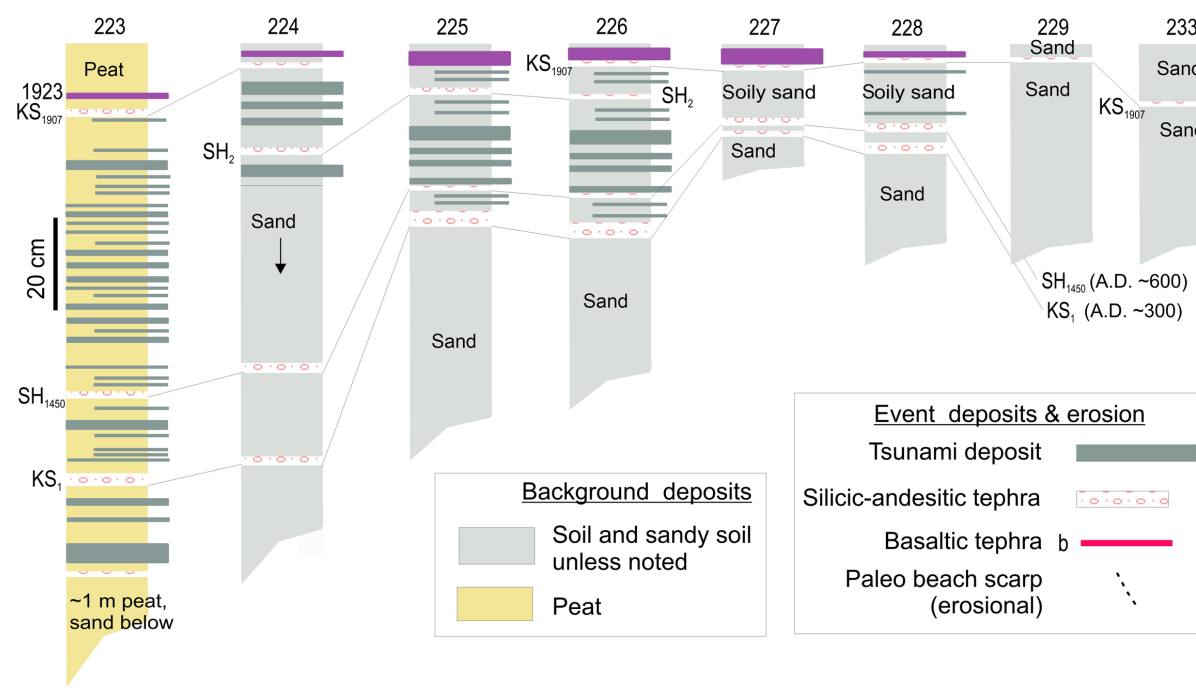

Figure 9. Example of two profiles that illustrate paleotsunami deposits used in analyses. Also see Figs. 4, 7, 8; tephra and tsunami deposits that are shown as narrower bands, e.g., 1997 in excavation 268, indicate thin, patchy deposits. Storozh profile 140 (a): here we use this profile to illustrate an analysis of tsunami deposits between $\mathrm{KS}_{1907}$ and $\mathrm{SH}_{2}$; note that the deposits thin landward, in general. In most excavations there are six tsunami deposits between $\mathrm{KS}_{1907}$ and $\mathrm{SH}_{2}$; excavation "x" has only three. Thus all six tsunamis reached "a" but only three reached " $x$ " or three of the six tsunamis only reached "a". All six tsunamis had to exceed the height of the shoreward beach ridge at the time of deposition. Chazhma profile 200 (b): as in profile 110 (Fig. 8), this profile has undergone uplift through time. For sub-SH $\mathrm{S}_{2}$ deposits, the profile was reconstructed to $4 \mathrm{~m}$ lower and $150 \mathrm{~m}$ narrower. Sites 229-233 are young; the profile from 228 landward is older than KS 1 ( AD 300). Site 223 is not far from the modern Chazhma River and in the past some tsunamis may have flooded this site via the river, when the profile was lower. Sites 226 and 225 both have six deposits between $\mathrm{SH}_{2}$ and $\mathrm{SH}_{1450}$; no other excavation on this profile provides a good count in this interval, but these six deposits probably are in the record at 223, and 224 was simply too sandy (lacking soil separation between layers) to count all layers in this interval. $\mathrm{SH}_{2}$ is not preserved (was not detected) in the peat excavation (223), but the 23 tsunami deposits in this excavation can be used in the overall count above $\mathrm{KS}_{1}$. Excavations 223, 225, and 226 all preserve tsunami deposits between $\mathrm{SH}_{1450}$ and $\mathrm{KS}_{1}$. In this interval the peat excavation (223) contains six deposits to the two in 225 and 226, for two possible reasons; first, peat is a better preserver/displayer of thin layers, and second, 223 is lower than 225 and 226, and at this time all were closer to shore. For the latter reason, 223 may have received tsunamis and their deposits directly from the river rather than over the beach ridge(s). 
ysis - at what frequencies do tsunamis occur and what is their size-frequency relationship?

\subsection{Occurrence and size}

For the record and analysis of tsunami deposits below $\mathrm{KS}_{1907}$, for each excavation we count the number of deposits between marker tephra and determine the approximate elevation above sea level and distance from shore of the excavation locale in that time (tephra) interval (Fig. S5; see Figs. 7, 8, 9 and their captions for more details on our interpretations). For some layers, an excavation may be their limit and for others not (e.g., Fig. 9). We do not attempt to correlate sand layers from excavation to excavation (or profile to profile), though there are cases where it is possible; the problem with distinguishing February 1923 from April 1923 deposits illustrates the potential for mis-correlation. The reasons that not all deposits are present in all excavations range from preservation to separation - for example, excavations near the coast will commonly contain amalgamated sand layers (e.g., Bourgeois et al., 2006). For each profile, we count the maximum number of tsunami deposits between tephra, which is our indication of how many tsunami events have occurred

In order to summarize paleotsunami sizes, we determine sediment runup - or the highest point seaward, whichever is higher - and sediment inundation for tsunami deposits on each profile. For each tephra interval along each profile, there will be deposits at maximum distances and maximum elevations; the two measures are treated separately because tsunami deposits are not correlated (in fact, high runup is associated with shorter, steeper profiles and long inundation with low-relief profiles). For example, for the historical deposits, two points are plotted (Fig. 10) - their point of maximum inundation and their point of maximum runup, which are usually on separate profiles.

A few of the paleo-events are comparable to Chile 1960 (Fig. 10), but most are likely from locally generated tsunamis because Chile 1960 was an outsized event, and its deposit is not well represented on the profiles. The 1997 tsunami has dimensions similar to the majority of paleotsunamis as represented by sediment runup on the order of 5-7 m (Fig. 10). The "1923" deposit (unknown if related to February, April, or both) is a "typical largest" event (Fig. 10). Recall that in these field sites there are few excavations at elevations of $10 \mathrm{~m}$ or more (Fig. S6), and that these higher elevations are on uplifted profiles, so in this situation we cannot have a record of older paleotsunamis reaching such elevations, simply as an artefact of the profile history (Fig. S5). This issue is present also for paleo-inundation on prograding profiles, but is not such a strong artefact in our data set. Overall, the number of deposits tends to decrease away from the coast and at higher elevations (density of points in Fig. 10), although there is a lot of scatter in the data, likely due to preservation and identification differences (e.g., Fig. 9).

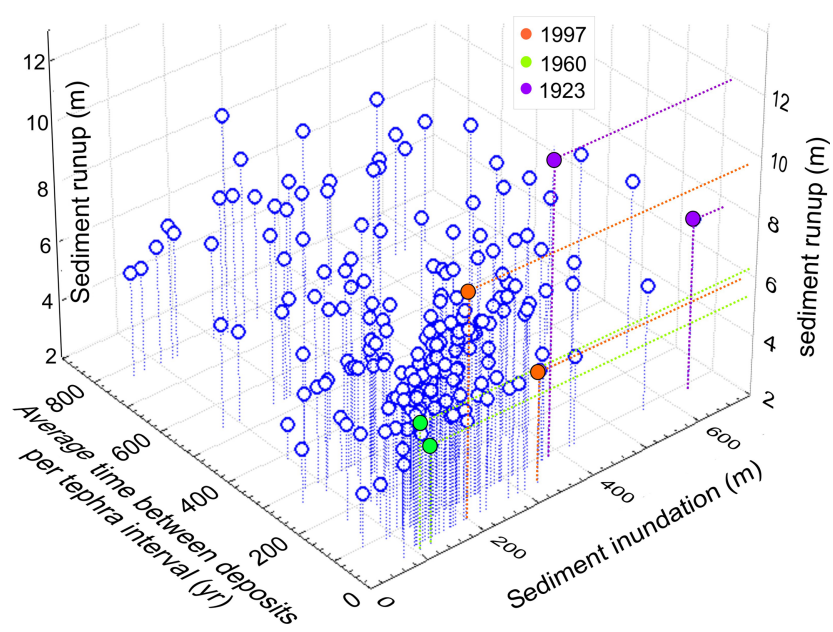

Figure 10. Three-dimensional diagram summarizing sediment runup and inundation for tsunami deposits, south Kamchatsky Bay, above $\mathrm{KS}_{1}$ tephra ( AD 300 up through AD 2000; from data plotted in Figs. S7 and S8). The three historical tsunami deposits are highlighted with their two points of maximum runup (and corresponding inundation at that point) and maximum inundation (and corresponding runup at that point), which do not coincide. For prehistoric events, we calculated (sediment) runup and inundation per tephra interval, with adjustments for changes through time in shoreline location and excavation elevation (see text and Fig. S5).

\subsection{Recurrence}

To determine tsunami recurrence according to size, we consider all tsunami deposits above $\mathrm{KS}_{1}(\sim \mathrm{AD} 300)$ at elevations greater than $5 \mathrm{~m}$ (Fig. 11). We only use excavations now at or reconstructed to be more than $5 \mathrm{~m}$ above sea level or landward of a beach ridge (reconstructed to be) higher than $5 \mathrm{~m}$ to be more confident we are analyzing tsunami deposits, not those of storms or floods, and to eliminate most non-local tsunamis. We did not use intermediate Shiveluch tephra layers between $\mathrm{KS}_{1907}$ and $\mathrm{KS}_{1}$ (Table 2) because their presence is not consistent enough to break down recurrence statistics, and the time intervals are short relative to the number of events, so statistical analysis cannot be supported. The grand total of the maximum number of events (per each interval) is 18 deposits, including the historical cases. For each event, we determine a maximum sediment runup, that is, if there are four deposits between two marker tephra on a given profile, we determine the four highest points those deposits reach; e.g., two may reach $8.3 \mathrm{~m}$ and the other two only $7.2 \mathrm{~m}$ (all four are considered to have reached $7.2 \mathrm{~m}$ ). We use reconstructed distances and elevations for each time interval below $\mathrm{KS}_{1907}$. The maximum elevation is either sediment runup ( $h$ ) or maximum elevation before sediment runup $(H$; as in Fig. 5), whichever is higher. Independent of the determined maximum elevation, we determine a maximum sediment inundation for each deposit in each tephra interval. 
All 18 deposits represent large tsunamis, reaching minimum elevations of $5 \mathrm{~m}$ (smaller not considered) and inland distances of $100 \mathrm{~m}$, with each factor having a recurrence interval of about 100 years (Fig. 11). Note again that runup and inundation are not paired; high runup commonly occurs on shorter, steeper profiles and long inundation on lower profiles. Tsunamis reaching an elevation of at least $7 \mathrm{~m}$ have a recurrence of $\sim 200$ years (Fig. 11). The largest reconstructed tsunamis as recorded by tsunami deposits have runup of $10 \mathrm{~m}$ or more and occur on average every 425 years. Tsunamis with inundation of $600 \mathrm{~m}$ or more occur on average every $\sim 570$ years.

\section{Discussion and conclusions}

\subsection{Historical tsunamis}

This work adds to the tsunami catalogue for 1997 Kronotsky and 1960 Chile, but not February or April 1923 Kamchatka events because we cannot differentiate between the (two) 1923 deposits. The near-field nature of the 1997 Kronotsky tsunami is significantly revised by our report of coastal profiles north of the Kronotsky Peninsula, adding substantial data to its catalogue. The 1997 tsunami reached runup heights of more than $9 \mathrm{~m}$, averaging $6 \mathrm{~m}$ over about $60 \mathrm{~km}$ of coastline. As would be expected, tsunami heights (as indicated by deposits) and inundation distances are influenced by coastal topography, with higher runups on steep profiles and longer inundation on lower-relief profiles. Data catalogues do not commonly provide topographic profiles, yet this information can be critical to understanding a tsunami and potentially its generating source.

Based on deposits from 15 profiles and more than 100 excavations, we conclude that in southern to central Kamchatsky Bay, the 1923 tsunami (February or April, indeterminate) was larger than the December 1997 Kronotsky tsunami, but the summary and tabulated data (Fig. 6, Table 3) are tricky to interpret, with sediment inundation $(L)$ being more indicative of tsunami size than runup $(h)$ or highest point seaward of runup ( $H$; e.g., see Fig. 5 illustration). On the basis of the total number of profiles exhibiting a deposit, "1923" is more extensive, but its average sediment runup $(h)$ value is lower because the farthest point it reached on a number of profiles is actually lower than the closer-to-shore points for 1997. Moreover, even though "1923" exceeded more of the high beach ridges seaward of the (sediment) runup point $(H)$, the average of those is almost the same as for 1997 (Table 3). Thus the most telling measurements distinguishing 1997 from "1923" are sediment inundation distances, with the average for "1923" almost twice that for 1997.

The 1952 tsunami deposit in southern Kamchatka (and the northern Kuril Islands; MacInnes et al., 2010) reaches greater heights and inundation distances along its earthquake rupture zone than any of the historical tsunami deposits along the

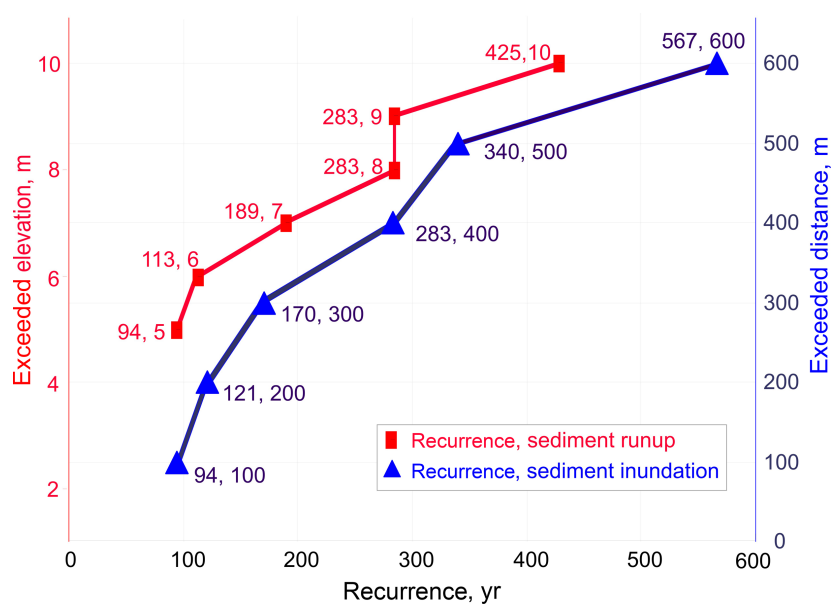

Figure 11. Tsunami $(>5 \mathrm{~m})$ recurrence for exceeded elevations (sediment runup) and exceeded distances from shoreline (sediment inundation) based on tsunami deposits since $\mathrm{KS}_{1}(\sim \mathrm{AD} 300)$ in south Kamchatsky Bay (for runup, integers of meters are shown; for inundation, multiples of $100 \mathrm{~m}$ ). For example, tsunamis with runup of $8-9 \mathrm{~m}$ or more occur on average every 283 years. Tsunamis exceeding inundation of $500 \mathrm{~m}$ occur on average every 340 years. Recall that runup and inundation are not paired (see text).

northern part of the Kamchatka subduction zone (this study; also Pinegina, 2014). While this observation is not surprising given that 1952 was $M_{\mathrm{w}} 9.0$ and the historical events to the north no larger than about $M_{\mathrm{W}} 8.5$, this leaves us with the question: can (does) the northern part of the subduction zone produce $M_{\mathrm{w}} 9$ events, or does Kronotsky Cape represent a locked or continuously slipping zone that keeps ruptures shorter, as in 1923? For that, we must turn to the prehistoric record.

\subsection{Implications for the 1997 Kronotsky earthquake rupture and the 1923 events}

The sediment runup and inundation data reported here require a reevaluation of rupture source models for the 1997 Kronotsky earthquake; we favor slip focused within the northern half of the aftershock zone shown in Fig. 2 (also see Fig. S9). Models which place most rupture energy to the south of or under the Kronotsky Peninsula (Fig. S9; e.g., Bürgmann et al., 2001, 2005; Llenos and McGuire, 2007; Bassett and Watts, 2015; Hayes, 2017) are not consistent with the tsunami data. The tsunami, rather than being unusually small for its generating earthquake's moment magnitude (Sohn, 1998), produced runup averaging $6 \mathrm{~m}$ over about $60 \mathrm{~km}$ of coastline, and $30 \mathrm{~cm}$ amplitude on the Hilo tide gage, requiring a "normal" offshore, subduction-zone rupture. Moreover, some significant portion of that rupture must be under substantial water depth to produce the indicated tsunami in the bay north of Kronotsky Cape, while not generating as much runup on the Cape, or to its south. While 
part of the rupture could well have been under the Kronotsky Peninsula and the relatively shallow region directly offshore, deformation in deeper water east and north of the peninsula is needed.

We conclude that a rupture consistent with the mainshock and aftershock locations from Kamchatka's network are more reasonable than more westerly locations, e.g., in the ISC catalogue (Fig. 2, Table S2). This issue is illustrated by the Hayes (2017) inversion, which takes the National Earthquake Information Center (NEIC) hypocentral location (Table S2) to start and, while this inversion results in most slip to the north (Fig. S9), locates that slip under the peninsula, where it cannot generate a tsunami. If this inversion were located based on the Kamchatka network's mapped mainshock, it might explain the 1997 tsunami.

The northern part of the Kamchatka subduction zone ruptured in two large tsunamigenic events in February 1923 and April 1923 (Fig. 1), and our study indicates that a substantial portion of the energy released by the 1997 Kronotsky earthquake was generated in a seismic gap between those earthquakes (and a large 24 February 1923 aftershock; Fig. 1), as originally recognized by Fedotov et al. (1998) and predicted by the authors' earlier work. The Kronotsky Peninsula lies landward of the (subducting) Emperor Seamount chain, which has been postulated to generate a locked or slowly slipping zone on the KSZ, a zone characterized by a relatively strong positive gravity anomaly (e.g., Bürgmann et al., 2005; Llenos and McGuire, 2007; Bassett and Watts, 2015; Fig. S9). The behavior of the subduction zone off/under Kronotsky Peninsula may have well kept the northern Kamchatka subduction zone from generating the 1952-scale $\left(M_{\mathrm{w}}\right.$ 9) Kamchatka earthquakes, but the 1997 tsunami is evidence that this segment does rupture.

\subsection{Paleotsunami results - implications for tectonic studies and hazard analyses}

The area of the southern to central Kamchatsky Bay contains a relatively short but well-preserved record of paleotsunami deposits which can be calibrated with the historical record. Combined with the record in northern Kamchatsky Bay (Pinegina et al., 2012; the north-central bay is characterized by cliffs), the pattern of runup and inundation in the prehistoric record for the last 1700 years does not diverge from the 20th century record. Compared with southern Kamchatka, the region where $M_{\mathrm{w}}$ 9-scale events occurred in 1952 and 1737, the northern subduction zone has generated smaller and less extensive tsunamis, in agreement with analyses of Bürgmann et al. (2005) for the modern and Pinegina (2014) for the prehistoric record.

A robust, 1700-year-long record may be sufficient to generate a probabilistic hazard analysis that can be used for both local and far-field hazard studies, and not only for tsunami recurrence statistics but also for recurrence statistics that include tsunami size. Reconstructing paleo-runup and paleo- inundation requires, and is thus limited by, accurate reconstructions of past shoreline locations and past (relative) sea levels. Coastlines with well-established marker tephra can enable such reconstructions, as shown by this study.

As are seismologists, paleoseismologists are cautioned to qualify our generalizations by the lessons of the 11 March 2011 Tohoku earthquake and tsunami. Characterizing subduction-zone behavior and quantifying its hazards are goals which we will only ever accomplish imperfectly.

Data availability. In addition to data presented in the text and supplement, additional supporting data are archived by the Russian Academy of Sciences Institute of Oceanology: http://disser.ocean. ru/index.php/dissertatsii/category/17-pinegina.html

\section{The Supplement related to this article is available online at https://doi.org/10.5194/nhess-18-335-2018- supplement.}

Author contributions. We contributed equally and together.

Competing interests. The authors declare that they have no conflict of interest.

Acknowledgements. Field research was supported by grants from the Russian Foundation for Basic Research (RFBR; 00-05-64697a to Tatiana K. Pinegina), the National Geographic Foundation to Vera Ponomareva, and the US National Science Foundation (EAR 9903341 to Joanne Bourgeois). Research and manuscript preparation were supported by RFBR grant 15-05-02651-a to Tatiana. K. Pinegina and a US Fulbright Foundation award to J. Bourgeois, which supported a visit to the Institute of Volcanology and Seismology, winter/spring of 2017.

We thank Vera Ponomareva for field advice and discussions regarding tephra stratigraphy and analysis; Alexander Lander for discussions concerning the nature of the 1997 Kronotsky earthquake; Alexander Gusev for discussions regarding the 1997 and earlier large earthquakes on Kamchatka; Vasily Titov for insights into the 1997 Kronotsky tsunami; and Vadim Saltykov for helpful recommendations about statistical analyses of tsunami recurrence. We are grateful to Alexander Storcheus (deceased), Leonid Kotenko, Ivan Storcheus and Edward Cranswick for their field assistance. Roland Bürgmann, Andrea Llenos and Gavin Hayes offered helpful insights into their source models for 1997 Kronotsky. We thank NHESS reviewers Serafina Barbano and Rob Witter for their thorough critiques.

Edited by: Ira Didenkulova

Reviewed by: Maria Serafina Barbano and Robert C. Witter 


\section{References}

Ammon, C. J., Kanamori, H., and Lay, T.: A great earthquake doublet and seismic stress transfer cycle in the central Kuril islands, Nature, 451, 561-565, https://doi.org/10.1038/nature06521, 2008.

Balakina, L. M.: The October 4, 1994 Shikotan and December 5, 1997 Kronotsky earthquakes and their strongest aftershocks as regular manifestations of the tectonic process in the KurilKamchatka seismogenic zone, Izvestiya - Russian Academy of Sciences, Physics of the Solid Earth, 36, 903-918, 2000.

Bassett, D. and Watts, A. B.: Gravity anomalies, crustal structure, and seismicity at subduction zones: 1 . Seafloor roughness and subducting relief, Geochem. Geophy. Geosy., 16, 1508-1540, https://doi.org/10.1002/2014GC005684, 2015.

Bourgeois, J.: Geologic effects and records of tsunamis, chap. 3 in The Sea, volume 15, Tsunamis, Harvard University Press, 55-91, 2009.

Bourgeois, J. and Titov, V. V.: A Fresh Look at the 1997 Kronosky Tsunami, Transactions of the European Geophysical Society, Abstracts, 2001.

Bourgeois, J., Pinegina, T., Ponomareva, V., and Zaretskaia, N.: Holocene tsunamis in the southwestern Bering Sea, Russian Far East, and their tectonic implications, Geol. Soc. Am. Bull., 118, 449-463, https://doi.org/10.1130/B25726.1, 2006.

Braitseva, O. A., Ponomareva, V. V., Sulerzhitsky, L. D., Melekestsev, I. V., and Bailey, J.: Holocene key-marker tephra layers in Kamchatka, Russia, Quaternary Res., 47, 125-139, https://doi.org/10.1006/qres.1996.1876, 1997.

Bürgmann, R., Kogan, M. G., Levin, V. E., Scholz, C. H., King, R. W., and Steblov, G. M.: Rapid aseismic moment release following the 5 December, 1997 Kronotsky, Kamchatka, earthquake, Geophys. Res. Lett., 28, 1331-1334, https://doi.org/10.1029/2000GL012350, 2001.

Bürgmann, R., Kogan, M. G., Steblov, G. M., Hilley, G., Levin, V. E., and Apel, E.: Interseismic coupling and asperity distribution along the Kamchatka subduction zone, J. Geophys. Res., 110, B07405, https://doi.org/10.1029/2005JB003648, 2005.

Fedotov, S. A., Chernyshev, S. D., Matviyenko, Y. D., and Zharinov, N. A.: Prediction of Kronotskoye earthquake of December 5, 1997, $M=7.8-7.9$, Kamchatka, and its strong aftershocks with $M>$ or $=6$, Volcanology and Seismology, 6, 3-16, 1998, (in Russian).

Godzikovskaya, A. A.: Summary of macroseismic information on Kamchatka earthquakes (Pre-instrumental and early instrumental observation period), Moscow - Petropavlovsk-Kamchatsky, 134 pp., 2010 (in Russian).

Gordeev, E. I., Ivanov, B. V., and Vikulin, A. V. (Eds.): Kronotskoye earthquake of December 5, 1997 on Kamchatka, PetropavlovskKamchatsky, Kamchatkan State Academy of Fishing Marine, 294 pp., 1998 (in Russian with English abstracts and figure captions).

Gordeev, E. I., Gusev, A. A., Levin, V. E., Bakhtiarov, V. F., Pavlov, V. M., Chebrov, V. N., and Kasahara, M.: Preliminary analysis of deformation of the Eurasia-Pacific-North America plate junction from GPS data, Geophys. J. Int., 147, 189-198, https://doi.org/10.1046/j.0956-540x.2001.01515.x, 2001.

Gusev, A. A.: The schematic map of the source zones of large Kamchatka earthquakes of the instrumental epoch: in Complex seismological and geophysical researches of Kamchatka, To 25th
Anniversary of Kamchatkan Experimental \& Methodical Seismological Department, edited by: Gordeev, E. I. and Chebrov, V. N., Petropavlovsk-Kamchatsky, 445 pp., 2004 (in Russian).

Gusev, A. A. and Shumilina, L. S.: Recurrence of Kamchatka strong earthquakes on a scale of moment magnitudes, Izvestiya, Physics of the Solid Earth, 40, 206-215, 2004.

Gusev, A. A., Levina, V. I., Saltykov, V. A., and Gordeev, E. I.: Large Kronotskoye earthquake of Dec. 5, 1997: basic data, seismicity of the epicentral zone, source mechanism, macroseismic effects, edited by: Gordeev, E. I., Ivanov, B. V., and Vikulin, A. V., 32-54, 1998 (in Russian with English abstract and figure captions).

Hayes, G. P.: The finite, kinematic rupture properties of great-sized earthquakes since 1990, Earth Planet. Sc. Lett., 468, 94-100, https://doi.org/10.1016/j.epsl.2017.04.003, 2017.

Kuzin, I. P., Levina, V. I., and Flenov, A. B.: Body wave velocity distribution in the Benioff zone of central Kamchatka during aftershocks of the Kronotskii earthquake of 1997 $(M=7.9)$, Journal of Volcanology and Seismology, 1, 175-184, https://doi.org/10.1134/S0742046307030037, 2007.

Kyle, P. R., Ponomareva, V. V., and Schluep, R. R.: Geochemical characterization of marker tephra layers from major Holocene eruptions, Kamchatka Peninsula, Russia, Int. Geol. Rev., 53, 1059-1097, https://doi.org/10.1080/00206810903442162, 2011.

Leonov, V. L.: Ground ruptures, landslides and rockfalls caused by the earthquake on December 5, 1997 at the sea-board of Kronotsky Peninsula, edited by: Gordeev, E. I., Ivanov, B. V., and Vikulin, A. V., 240-246, 1998 (in Russian).

Levina, V. I., Lander, A. V., Mityushkina, S. V., and Chebrova, A. Y.: The seismicity of the Kamchatka region: 19622011, Journal of Volcanology and Seismology, 7, 37-57, https://doi.org/10.1134/S0742046313010053, 2013.

Llenos, A. L. and McGuire, J. J.: Influence of forearc structure on the extent of great subduction zone earthquakes, J. Geophys. Res.-Sol. Ea., 112, B09301, https://doi.org/10.1029/2007JB004944, 2007.

Liu, P. L. F.: Tsunami modeling: propagation, The Sea, 15, 295 319, 2009

MacInnes, B. T., Pinegina, T. K. Bourgeois, J., Razhigaeva, N. G., Kaistrenko, V. M., and Kravchunovskaya, E. A.: Field survey and geological effects of the 15 November 2006 Kuril tsunami in the middle Kuril Islands: In Tsunami Science Four Years after the 2004 Indian Ocean Tsunami, Birkhäuser Basel, 9-36, https://doi.org/10.1007/s00024-008-0428-3, 2009.

MacInnes, B. T., Weiss, R., Bourgeois, J., and Pinegina, T. K.: Slip distribution of the 1952 Kamchatka great earthquake based on near-field tsunami deposits and historical records, B. Seismol. Soc. Am., 100, 1695-1709, https://doi.org/10.1785/0120090376, 2010.

MacInnes, B., Kravchunovskaya, E., Pinegina, T., and Bourgeois, J.: Paleotsunamis from the central Kuril Islands segment of the Japan-Kuril-Kamchatka subduction zone, Quaternary Res., 86, 54-66, https://doi.org/10.1016/j.yqres.2016.03.005, 2016.

Martin, M. E., Weiss, R., Bourgeois, J., Pinegina, T. K, Houston, H., and Titov, V. V.: Combining constraints from tsunami modeling and sedimentology to untangle the 1969 Ozernoi and 1971 Kamchatskii tsunamis, Geophys. Res. Lett., 35, L01610, https://doi.org/10.1029/2007GL032349, 2008. 
Melekestsev, I. V, Braitseva, O. A., Erlikh, E. N., Shantser, A. E., Chelebaeva, A. I., Lupikina, E. G., Egorova, I. A., and Kozhemyaka, N. N.: Kamchatka, Komandor and Kurile Islands, Moscow, Nauka, 439 pp., 1974 (in Russian).

NCEI, National Centers for Environmental Information (formerly NGDC): Natural Hazards Data, Images and Education, Tsunami and Earthquake databases, https://www.ngdc.noaa.gov/hazard/ hazards.shtml, last access: 12 May 2017.

Okal, E. A. and Synolakis, C. E.: Source discriminants for near-field tsunamis, Geophys. J. Int., 158, 899-912, https://doi.org/10.1111/j.1365-246X.2004.02347.x, 2004.

Petukhin, A. G., Dontsov, O. V., Kozlov, V. N., and Sinitsyn, V. I.: Preliminary analysis of strong ground-motion records of the Kronotskoye earthquake of December 5, $1997\left(M_{\mathrm{W}}=7.9\right)$, edited by: Gordeev, E. I., Ivanov, B. V., and Vikulin, A. V., 247-256, 1998 (in Russian with English abstract and figure captions).

Pinegina, T. K.: Time-space distribution of tsunamigenic earthquakes along the Pacific and Bering coasts of Kamchatka: insight from paleotsunami deposits, Doctor of Geological Science dissertation, Institute of Oceanology RAS, Moscow, 235 pp., 2014 (in Russian).

Pinegina, T. K., Kozhurin, A. I., and Ponomareva, V. V.: Seismic and tsunami hazard assessment for Ust-Kamchatsk settlement, Kamchatka, based on paleoseismological data, Bulletin of Kamchatka regional association "Educational-scientific center", Earth Sci., 1, 138-159, 2012 (in Russian with English abstract).

Pinegina, T. K., Bourgeois, J., Kravchunovskaya, E. A., Lander, A. V., Arcos, M. E., Pedoja, K., and MacInnes, B. T.: A nexus of plate interaction: Vertical deformation of Holocene wave-built terraces on the Kamchatsky Peninsula (Kamchatka, Russia), Geol. Soc. Am. Bull., 125, 1554-1568, https://doi.org/10.1130/B30793.1, 2013.
Ponomareva, V., Portnyagin, M., Pendea, I. F., Zelenin, E., Bourgeois, J., Pinegina, T., and Kozhurin A. A.: A full Holocene tephrochronology for the Kamchatsky Peninsula region: applications from Kamchatka to North America, Quaternary Sci. Rev., 168, 101-122, https://doi.org/10.1016/j.quascirev.2017.04.031, 2017.

Slavina, L. B., Pivovarova, N. B., and Levina, V. I.: A study in the velocity structure of December 5, 1997, $M_{\mathrm{W}}=7.8$ Kronotskii rupture zone, Kamchatka, J. Volcanol. Seismol., 1, 254-262, https://doi.org/10.1134/S0742046307040045, 2007.

Sohn, S. W.: The 1997 Kamchatka earthquake. Individual Studies by Participants at the International Institute of Seismology and Earthquake Engineering, Tokyo, International, 34, 91-99, 1998.

Song, T. R. A. and Simons, M.: Large trench-parallel gravity variations predict seismogenic behavior in subduction zones, Science, 301, 630-633, https://doi.org/10.1126/science.1085557, 2003.

Troshin, A. N. and Diaghilev, G. A.: The Ust' Kamchatsk earthquake of April 13, 1923, Library Institute Physics Earth, Akad. Nauk SSSR, Moskva, 1926 (in Russian).

Zayakin, Y. A. and Luchinina, A. A.: Catalogue tsunamis on Kamchatka, Obninsk: Vniigmi-Mtsd, 51 pp., 1987 (Booklet in Russian).

Zayakin, Y. A. and Pinegina, T. K.: Tsunami in Kamchatka on December 5, 1997, edited by: Gordeev, E. I., Ivanov, B. V., and Vikulin, A. V., 257-263, 1998 (in Russian with English abstract and figure captions).

Zobin, V. M. and Levina, V. I.: The rupture process of the $M_{\mathrm{W}} 7.8$ Cape Kronotsky, Kamchatka, earthquake of 5 December 1997 and its relationship to foreshocks and aftershocks, B. Seismol. Soc. Am., 91, 1619-1628, https://doi.org/10.1785/0119990116, 2001. 